\title{
Peningkatan Pengetahuan dan Pemahaman Masyarakat Nagari Pasie Laweh tentang Kekerasan Terhadap Perempuan dan Anak melalui Penyuluhan
}

\author{
Fatmariza $^{1 *}$, Henni Muchtar ${ }^{1}$, Susi Fitria Dewi ${ }^{2}$, Irwan $^{3}$, Ideal Putra ${ }^{4}$, Yurni Suasti ${ }^{5}$, Rika Febriani $^{6}$ \\ ${ }^{1}$ Jurusan Ilmu Sosial Politik, Fakultas Ilmu Sosial Universitas Negeri Padang \\ 5. Jurusan Geografi, Fakultas Ilmu Sosial Universitas Negeri Padang \\ *Penulis Korespondensi, Fatmariza Jurusan Ilmu Sosial Politik Universitas Negeri Padang 71572. Email: \\ fatmariza@fis.unp.ac.id
}

\begin{abstract}
ABSTRAK
Kekerasan terhadap perempuan dan anak di daerah pedesaan masih sedikit yang tercatat dan dilaporkan. Hal ini disebabkan karena kasus lebih banyak diselesaikan secara adat sehingga penyelesaiannya seringkali mengabaikan korban. Beberapa faktor yang menyebabkan hal ini terjadi diantaranya adalah rendahnya pengetahuan dan pemahaman masyarakat, kurangnya perhatian dan kepedulian tokoh-tokoh masyarakat dan Pemerintah Desa, serta rendahnya akses masyarakat terhadap informasi terkait kekerasan. Menyikapi persoalan tersebut, penulis melakukan penyuluhan tentang berbagai aspek terkait kekerasan terhadap perempuan dan anak kepada masyarakat Nagari Pasie Laweh, Kecamatan Lubuk Alung Kabupaten Padang Pariaman. Kegiatan penyuluhan ini diikuti oleh perempuan dan laki-laki yang mewakili berbagai kelompok masyarakat. Materi yang disampaikan berkaitan dengan kekerasan terhadap perempuan dan anak, perlindungan hukum, budaya yang menyebabkan kekerasan terhadap perempuan dan anak, dampak serta peran tokoh masyarakat dan Pemerintah Nagari dalam pencegahan kekerasan terhadap perempuan dan anak. Hasil penyuluhan menunjukkan bahwa pengetahuan dan pemahaman masyarakat tentang kekerasan terhadap perempuan dan anak semakin baik, namun belum utuh. Masyarakat masih menganggap bentuk kekerasan adalah dalam bentuk luka fisik. Padahal ada bentuk kekerasan lain seperti kekerasan yang bersifat psikologis. Sikap masyarakat juga semakin baik karena tidak lagi menganggap kekerasan terhadap perempuan sebagai aib yang harus ditutupi. Masyarakat juga sudah paham tindakan yang harus dilakukan apabila terjadi kekerasan. Di samping itu, mereka juga merasa perlu adanya lembaga khusus di desa untuk memudahkan akses penanganan kekerasan. Berdasarkan hasil kegiatan penyuluhan ini, memperlihatkan adanya peningkatan pengetahuan, sikap yang baik, tindakan yang tepat oleh masyarakat dalam upaya mencegah dan menangani masalah kekerasan terhadap perempuan dan anak di Nagari tersebut
\end{abstract}

Kata Kunci: Kekerasan, Perempuan, Anak, Nagari, Patriarkhi

\begin{abstract}
Violence against women and children (VAWC) in rural areas is still little recorded and reported. This is because more cases are settled by custom, so the resolution often ignores victims. Some factors that cause this to happen include the low level of knowledge and understanding of the community, lack of attention and concern from community leaders and village government, as well as low community access to information. Responding to this problem, the authors conducted counseling on various aspects related to VAWC in the Nagari Pasie Laweh community, Lubuk Alung District, Padang Pariaman Regency. This counseling activity was attended by women and men who represented various community groups. The material presented in this activity relates to VAWC, legal protection, culture that causes VAWC, the impact and role of community leaders and the Nagari Government in preventing VAWC. The results of the counseling show that the community's knowledge and understanding of VAWC is getting better, but not yet intact. Society still considers this form of violence as physical injury. Though there are other forms of violence such as psychological violence. The attitude of the community is also getting better because they no longer consider violence against women as a disgrace that must be covered up. The community also understands the actions that must be taken if violence occurs. In addition, they also felt the need for special institutions in the village to facilitate access to handling violence. Based on the
\end{abstract}


results of these outreach activities, there was an increase in knowledge, good attitudes, appropriate actions by the community in an effort to prevent and deal with the problem of VAWC in Nagari

Keywords: Women Violence, Children, Nagari, Patriarchy

\section{PENDAHULUAN}

\section{Analisis Situasi}

Kekerasan terhadap perempuan dan anak merupakan fenomena gunung es. Karena fakta yang sesungguhnya ada di dalam masyarakat jauh lebih banyak dibandingkan dengan jumlah kasus yang terungkap ke publik. Hal ini terjadi, karena isu kekerasan terhadap perempuan terutama Kekerasan Dalam Rumah Tangga (KDRT) dan kekerasan/pelecehan seksual merupakan isu yang berkelindan dengan nilai-nilai patriarkhis yang menempatkan perempuan dan masalah-masalah yang dialaminya pada posisi yang relatif tertutup, privat dan dianggap "aib". Sehingga masyarakat maupun korban menganggap persoalan tersebut tidak baik bila diberitahukan kepada orang lain apalagi menyangkut nama baik keluarga.

Catatan tahunan Komnas Perempuan tahun 2017 mencatat bahwa kekerasan terhadap istri (KTI) menempati peringkat pertama 5.784 kasus (56\%), disusul kekerasan dalam pacaran 2.171 kasus (21\%), kekerasan terhadap anak perempuan 1.799 kasus (17\%) dan sisanya kekerasan mantan suami, kekerasan mantan pacar, serta kekerasan terhadap pekerja rumah tangga. Kekerasan di ranah komunitas mencapai angka 3.092 kasus (22\%), di mana kekerasan seksual menempati peringkat pertama sebanyak 2.290 kasus (74\%), diikuti kekerasan fisik 490 kasus (16\%) dan kekerasan lain di bawah angka 10\%; yaitu kekerasan psikis 83 kasus (3\%), buruh migran 90 kasus (3\%); dan trafiking 139 kasus (4\%). Jenis kekerasan yang paling banyak pada kekerasan seksual di ranah komunitas adalah perkosaan (1.036 kasus) dan pencabulan (838 kasus).

Kekerasan terhadap istri menempati urutan pertama yang mencapai 56 persen dari keseluruhan jenis kekerasan terhadap perempuan. Sementara kekerasan seksual yang pada umumnya menimpa anak-anak perempuan adalah adalah perkosaan dan pencabulan yang mencapai 1874 kasus pada tahun 2017. Jenis kekerasan ini biasanya terjadi di dalam rumah dan dilakukan oleh orang-orang terdekat. Oleh karena itu, isu ini sangat urgen untuk diperhatikan dan dicarikan solusinya. Permasalahan kekersan terhadap perempuan dan anak mengandung kompleksitas yang tinggi. Oleh karena itu tidak bisa diselesaikan melalui satu aspek saja, apalagi secara terpisah-pisah. Dengan demikan, semua pihak harus senantiasa bersinergi, baik pemerintah, masyarakat, LSM, kepolisian, maupun perguruan tinggi melalui kegiatan pengabdian kepada masyarakat. Secara politis, untuk memperbaiki kondisi diskriminasi dan ketidakadilan gender, pemerintah juga sudah mencanangkan partisipasi seluruh lembaga baik di pusat maupun di daerah untuk melakukan Pengarus Utamaan Gender (PUG) melalui Impres nomor 9 tahun 2000, program Three Ends (Akhiri kemiskinan perempan, akhiri kekerasan terhadap perempuan dan anak, akhiri perdagangan perempuan) yang digagas oleh Kementerian PPA.

Selanjutnya, berdasarkan data dari Catatan Tahunan (Catahu) Komnas Perempuan tahun 2018 Kekerasan Terhadap Perempuan di Sumatera Barat menempati urutan ke-5 tertinggi di Indonesia sesudah DKI Jakarta, Jawa Barat, Jawa Timur dan Jawa Tengah. Hal ini sangat ironis karena terjadi di wilayah yang memiliki kearifan lokal matrilineal yang seharusnya dapat menghargai dan melindungi perempuan dan anak secara lebih baik dibandingkan daerah lain yang tidak matrilineal. Selain itu, unsur-unsur ikatan sosial Secara lebih rinci kondisi tingkat 


\section{VIVABIO}

\section{Jurnal Pengabdian Multidisiplin}

kekerasan terhadap perempuan di Indonesia dapat dilihat pada gambar di bawah ini

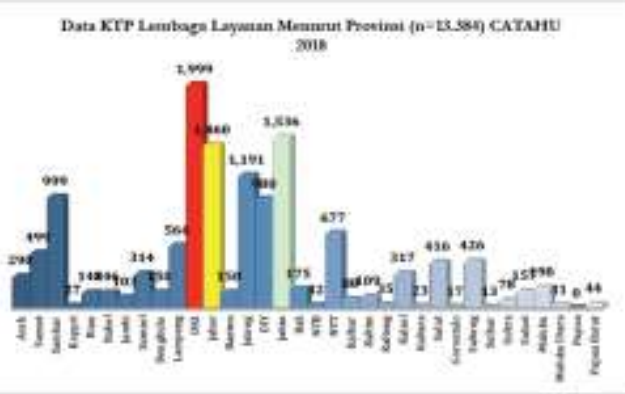

Gambar 1:Jumlah Kekerasan Tehadap

Perempuan (KTP) Berdasarkan Propinsi

Tahun 2018

Relatif berbeda dengan kejahatan lainnya, kekerasan terhadap perempuan dan anak terjadi antar dua pihak dengan relasi kuasa yang tidak seimbang, serta dominasi patriarkhi. Banton, O, \& West, K (2019) menjelaskan bahwa pelaku kejahatan seksual terhadap anak identik dilakukan oleh laki-laki. Penelitian lainnya berkaitan dengan budaya patriarki sebagai faktor dominan penyebab kekerasan terhadap perempuan dan anak (Muhajarah, 2016 ; Sakina dkk, 2017). Selanjutnya Fadillah dkk (2020) menemukan bahwa kekerasan di dalam masyarakat juga di latar belakangi oleh faktor budaya. Sementara Fatmariza dan Rika Febriani (2019) menemukan bahwa posisi perempuan minang dalam keluarga modern relatif lebih rentan terhadap kekerasan terutama berkaitan dengan semakin jaraknya perempuan dengan kerabat matrilineal. Artinya, pelaku kekerasan adalah individu maupun kelompok yang memiliki kuasa (fisik, sosial, ekonomi, status) lebih kuat dibandingkan para korban perempuan. Berbagai faktor menjadi pemicu terjadinya kekerasan terhadap perempuan dan anak di Sumatera Barat, diantaranya adalah: tingkat pendidikan, ekonomi, usia dan kepribadian pelaku, apatisme masyarakat, serta anggapan "aib" keluarga (Fatmariza; 2018). Selain itu, masyarakat belum sepenuhnya memahami persoalan kekerasan terhadap perempuan dan anak, serta perhatian pemerintah desapun masih rendah. Seringkali masalah kekerasan terhadap perempuan dan anak yang terjadi dalam rumah tangga dianggap urusan keluarga yang bersangkutan. kekerasan terhadap perempuan masih terjadi di dalam

\section{Tujuan dan Manfaat Kegiatan}

Sesuai dengan rencana kegiatan, maka tujuan dan manfaat kegiatan pengabdian pada masyarakat ini adalah :

a) Meningkatnya pengetahuan dan pemahaman masyarakat peserta penyuluhan tentang kekerasan terhadap perempuan dan anak

b) Meningkatnya pengetahuan dan keterampilan masyarakat peserta penyuluhan dalam melakukan pencegahan dan penangan kekerasan terhadap perempuan dan anak

c) Tumbuhnya kepedulian masyarakat peserta penyuluhan akan pentingnya lembaga perlindungan perempuan dan anak di tingkat Nagari

\section{METODE PELAKSANAAN}

\section{Sasaran kegiatan}

Yang menjadi sasaran pelaksanaan kegiatan penyuluhan ini adalah masyarakat Nagari Pasie Laweh, yang terdiri dari perwakilan tokoh adat, tokoh agama, guru, pemerintah Nagari, kelompok perempuan, dan pemuda yang berjumlah 60 orang.

\section{Lokasi kegiatan}

Kegiatan penyuluhan dilakukan di Nagari Pasie Laweh Kecamatan Lubuk Alung Kabupaten Padang Pariaman.

\section{Metode yang digunakan}

Metode yang digunakan dalam kegiatan ini adalah penyuluhan, dengan penyajian materi oleh narasumber menggunakan beberapa seperti teknik ceramah, diskusi, dan dialog atau tanya jawab. Pelaksanaan penyuluhan menggunakan prinsip pendidikan orang dewasa. Artinya, tidak ada jarak antara penyaji dengan peserta. Dengan demikian, diskusi dapat berjalan secara setara. Pemaparan materi penyuluhan dibantu dengan media power point, gambar, film, dan kartu. Setelah selesai penyuluhan, data dikumpulkan melalui kuesioner terkait tingkat pengetahuan 


\section{VIVABIO}

\section{Jurnal Pengabdian Multidisiplin}

dan pemahaman peserta tentang isu kekerasan terhadap perempuan dan anak

\section{HASIL DAN PEMBAHASAN}

Pada bahagian ini dipaparkan sebahagian hasil kegiatan pengabdian masyarakat terkait dengan upaya peningkatan pengetahuan dan kepedulian masyarakat dan pemerintah Nagari terhadap persoalan kekerasan terhadap perempuan dan anak. Kegiatan yang dilakukan dalam bentuk penyuluhan ini, secara khusus bertujuan untuk meningkatkan pengetahuan dan kepedulian masyarakat dan aparatur pemerintah Nagari dalam menghupus kekerasan terhadap perempuan dan anak. Sehingga pada gilirannya, akan terwujud Nagari yang bebas dari segala bentuk kekerasan terhadap perempuan dan anak.

Artikel ini akan memaparkan hasil kegiatan pengabdian masyarakat terutama berkaitan dengan analisis kuesioner yang diisi oleh peserta penyuluhan di akhir kegiatan penyuluhan. Paparan dikelompokkan atas tiga bahagian, yakni berkaitan dengan pengetahuan, sikap dan tindakan masyarakat terhadap kasus kekerasan terhadap perempuan dan anak.

\section{A. Pengetahuan Masyarakat tentang Kekerasan terhadap Perempuan dan Anak}

Pengetahuan masyarakat tentang berbagai kasus kekerasan terhadap perempuan dan anak sudah cukup baik. Istilah KDRT misalnya sudah sangat familiar bagi masyarakat. Berbagai kasus KDRT yang terjadi pada awalnya masyarakat masih menganggap "aib" karena itu sebahagian peserta masih mempertanyakan resiko yang harus ditanggung apabila kasus KDRT diungkap. Hal ini memang menjadi masalah yang seringkali dihadapi perempuan korban. Ada kasus-kasus KDRT yang dilaporkan, bahkan sampai di Kepolisian, namun seringkali korban mencabut kembali laporannya. Banyak alasan yang dikemukakan mengapa cukup banyak laporan yang dicabut kembali oleh perempuan korban. Di antaranya adalah ketergantungan ekonomi keluarga kepada suami (Sutrisminah, 2012), ketidaknyamanan perempuan korban di tengah masyarakat yang masih cenderung menyalahkan perempuan yang menjadi korban, bantuan hukum yang belum memadai terhadap korban, alasan psikologis dan sosiologis, rasa bersalah perempuan (self guilty) pada perempuan, serta tekanan sosial lainnya terhadap perempuan korban. Hal ini sejalan dengan beberapa temuan penelitian Fatmariza, (2008).

Pengetahuan masyarakat tentang berbagai hal berkaitan dengan kekerasan terhadap perempuan dan anak dapat dilihat pada

Tabel 1.

Tabel 1. Pengetahuan Masyarakat tentang Kekerasan terhadap Perempuan

\begin{tabular}{|c|c|c|c|c|c|c|c|c|c|c|c|}
\hline \multirow[t]{2}{*}{ No } & \multirow[t]{2}{*}{ Pernyataan } & \multicolumn{2}{|c|}{ S S } & \multicolumn{2}{|l|}{$\mathrm{S}$} & \multicolumn{2}{|l|}{ T S } & \multicolumn{2}{|c|}{$\begin{array}{l}\text { STS } \\
\end{array}$} & \multicolumn{2}{|c|}{$\mathrm{Jml}$} \\
\hline & & f & $\%$ & $\mathrm{f}$ & $\%$ & $\mathrm{f}$ & $\%$ & $\mathrm{~F}$ & $\%$ & f & $\%$ \\
\hline 1 & $\begin{array}{l}\text { Kekerasan terhadap perempuan dan } \\
\text { anak adalah apabila mengakibatkan } \\
\text { luka fisik }\end{array}$ & 15 & 26.3 & 20 & 35.0 & 15 & 26.3 & 7 & 12.3 & 57 & 100 \\
\hline 2 & $\begin{array}{l}\text { Kekerasan terhadap perempuan dan } \\
\text { anak adalah apabila mengakibatkan } \\
\text { korban merasa takut dan terhina }\end{array}$ & 14 & 24.6 & 21 & 36.8 & 12 & 21.0 & 10 & 17.5 & 57 & 100 \\
\hline 3 & $\begin{array}{l}\text { Beban ganda perempuan adalah salah } \\
\text { satu bentuk kekerasan }\end{array}$ & 1 & 1.7 & 9 & 15.8 & 38 & 66.7 & 9 & 15.8 & 57 & 100 \\
\hline 4 & $\begin{array}{l}\text { Penelantaran perempun dan anak } \\
\text { adalah bntuk kekerasan }\end{array}$ & 9 & 15.8 & 22 & 38.6 & 22 & 38.6 & 4 & 7.0 & 57 & 100 \\
\hline 5 & $\begin{array}{l}\text { Melarang istri bersosialisasi dengan } \\
\text { orang lain adalah bentuk kekerasan }\end{array}$ & 6 & 10.5 & 27 & 47.4 & 20 & 35.0 & 4 & 7.0 & 57 & 100 \\
\hline
\end{tabular}




\section{VIVABIO}

Jurnal Pengabdian Multidisiplin

Data Tabel 1 menunjukkan bahwa sebahagian besar responden setuju bahwa kekerasan terhadap perempuan dan anak adalah apabila mengakibatkan luka fisik, yakni sebanyak 26.3 persen sangat setuju, dan 35.0 persen setuju. Meskipun demikian masih ada sebanyak12.3 persen responden yang menyatakan tidak setuju. Hal ini disebabkan oleh beberapa kemungkinan, di antaranya kesalahan memahami pernyataan, atau responden memiliki pengetahuan bahwa akibat kekerasan terhadap perempuan dan anak tidak hanya luka fisik. Jika alasannya adalah yang kedua, maka dapat diartikan bahwa sesungguhnya responden telah mempunyai pengetahuan yang baik tentang akibat kekerasan terhadap perempuan dan anak.

Tidak jauh berbeda dengan pernyataan pertama, pada pernyataan kedua sebahagian besar responden setuju dan bahkan ada sebanyak 24.6 persen responden yang sangat setuju bahwa kekerasan terhadap perempuan adalah yang mengakibatkan rasa takut dan terhina pada perempuan. Artinya responden mengetahui bahwa akibat kekerasan terhadap perempuan tidak hanya dalam bentuk fisik, tetapi juga dalam bentuk psikologis yakni rasa takut dan terhina.

Berbeda dengan pernyataan sebelumnya, sebahagian besar responden justru tidak setuju apabila beban ganda perempuan merupakan bentuk kekerasan terhadap perempuan. Hal ini dapat dilihat bahwa terdapat 66.7 persen responden tidak setuju, dan 15.8 persen menyatakan sangat tidak setuju. Data ini menunjukkkan bahwa beban ganda perempuan dianggap bukan kekerasan karena sejauh ini beban ganda pada perempuan dianggap sebagai sesuatu yang umum dan lumrah di dalam masyarakat. Hal ini juga sebagai akibat kerjakerja domestik yang sepenuhnya menjadi tanggung jawab perempuan sementara kerjakerja produktif dapat dilakukan oleh laki-laki dan perempuan. Beban ganda akan semakin berat pada perempuan kelas bawah. Selain karena masalah ekonomi, seringkali masyarakat kelas bawah kurang memiliki pengetahuan dan pemahaman yang baik tentang kesetaraan gender. Masyarakat masih relatif kuat terikat dengan nilai-nilai patriarkhis yang lebih banyak merugikan perempuan.

Terkait dengan penelantaran perempuan dan anak sebagai bentuk kekerasan, sebanyak 38.6 persen responden menyatakan tidak setuju. Bahkan masih ada sebanyak 7.0 persen yang memilih sangat tidak setuju. Demikian juga halnya dengan melarang istri bersosialisasi sebanyak 35.0 persen responden menyatakan tidak setuju dan 7.0 persen responden menyatakan sangat tidak setuju.

Berdasarkan data di atas dapat disimpulkan bahwa masyarakat belum memiliki pengetahuan yang utuh tentang berbagai bentuk kekerasan terhadap perempuan. Sebahagian besar masyarakat masih beranggapan bahwa kekerasan terhadap perempuan adalah apabila mengakibatkan luka fisik. Padahal secara teoritis terdapat minimal 5 bentuk kekerasan terhadap perempuan yakni; kekerasan fisik, kekerasan psikhis, kekerasan verbal, kekerasan ekonomi dan penelantaran, kekerasan seksual (UU Nomor 23 tahun 2004). Beban ganda adalah salah satu bentuk manifestasi ketidakadilan gender yang pada gilirannya dapat menjadi bentuk kekerasan.

\section{B. Sikap Masyarakat terhadap Kekerasan terhadap Perempuan dan Anak}

Selanjutnya gambaran sikap masyarakat terhadap fenomena kekerasan terhadap perempuan dan anak dapat dilihat pada data Tabel 2. 
Tabel 2. Sikap Masyarakat terhadap Kekerasan terhadap Perempuan

\begin{tabular}{|c|c|c|c|c|c|c|c|c|c|c|c|}
\hline \multirow[b]{2}{*}{ No } & \multirow[t]{2}{*}{ Pernyataan } & \multicolumn{2}{|c|}{ S S } & \multicolumn{2}{|l|}{$\mathrm{S}$} & \multicolumn{2}{|c|}{ T S } & \multicolumn{2}{|c|}{ STS } & \multicolumn{2}{|c|}{$\mathrm{Jml}$} \\
\hline & & F & $\%$ & $f$ & $\%$ & $\mathrm{f}$ & $\%$ & $\mathrm{~F}$ & $\%$ & $f$ & $\%$ \\
\hline 1 & $\begin{array}{l}\text { Kekerasan terhadap perempuan dan anak } \\
\text { adalah masalah internal/pribadi, orang lain } \\
\text { tidak berhak campur tangan }\end{array}$ & 7 & 12.3 & 19 & 33.3 & 25 & 43.8 & 6 & 10.5 & 57 & 100 \\
\hline 2 & $\begin{array}{l}\text { Perempuan harus merahasiakan kekerasan } \\
\text { yang dilakukan oleh suaminya. Itu aib rumah } \\
\text { tangga }\end{array}$ & 0 & 0 & 7 & 12.3 & 40 & 70.2 & 10 & 17.5 & 57 & 100 \\
\hline 3 & $\begin{array}{l}\text { Kekerasan dalam rumah tangga adalah hal } \\
\text { yang tidak pantas diceritakan kepada orang } \\
\text { lain }\end{array}$ & 6 & 10.5 & 15 & 26.3 & 30 & 52.6 & 6 & 10.5 & 57 & 100 \\
\hline 4 & $\begin{array}{l}\text { Jika saya mengalami kekerasan saya memilih } \\
\text { untuk diam, karena tidak ingin orang lain } \\
\text { mengetahui }\end{array}$ & 6 & 10.5 & 10 & 17.5 & 32 & 56.1 & 9 & 15.8 & 57 & 100 \\
\hline 5 & $\begin{array}{l}\text { Suami adalah tulang punggung keluarga. } \\
\text { Oleh karena itu tidak perlu dilaporkan bila } \\
\text { dia melakukan kekerasan terhadap istri dan } \\
\text { anak }\end{array}$ & 2 & 3.5 & 5 & 8.8 & 33 & 57.9 & 17 & 29.8 & 57 & 100 \\
\hline
\end{tabular}

Sumber: Data Primer 2019

Data Tabel 2 menunjukkan bahwa 33.3 persen responden menyatakan setuju bahwa kekerasan terhadap perempuan dan anak adalah masalah pribadi sehingga orang lain tidak berhak ikut campur. Bahkan ada sebanyak 12.3 persen yang menyatakan sangat setuju. Data ini menunjukkan bahwa sikap masyarakat terkait persoalan kekerasan terhadap perempuan dan anak dapat menjadi penghambat dalam mengungkap kasus-kasus kekerasan terhadap perempuan dan anak. Hal ini menjadi salah satu faktor yang menyebabkan jumlah kekerasan terhadap perempuan dan anak yang sesungguhnya terjadi di dalam masyarakat jauh lebih banyak dibandingkan dengan jumlah yang terekspos dan tercatat. Sikap masyarakat yang demikian juga dapat melanggengkan berbagai bentuk kekerasan terhadap perempuan dan anak, karena tidak ada efek jera terhadap pelaku.

Berbeda dengan sikap di atas, terkait dengan kekerasan yang dilakukan suami terhadap istri (KDRT) sebanyak 70.2 persen responden tidak setuju apabila kasus tersebut dirahasiakan dan dianggap "aib". Sebanyak 17.5 persen responden menyatakan sangat tidak setuju apabila kasus tersebut dirahasialan dan dianggap aib. Data ini menunjukkan bahwa sebahagian besar responden sekitar 87 persen bersikap bahwa kasus KDRT suami terhadap istri bukanlah aib, karena itu harus diungkap.
Data tersebut dapat diartikan bahwa masyarakat mulai memiliki sikap yang baik terhadap isu-isu KDRT. Sikap seperti ini dapat membatu upaya penghapusan kekerasan terhadap perempuan dan anak.

Data table 2 juga menunjukkan sikap responden apabila mengalami kekerasan. Sebanyak 56.1 persen menyatakan tidak setuju kasus kekerasan yang dialaminya didiamkan. 15.8 persen menyatakan sangat tidak setuju bila kasus tersebut didiamkan. Data ini mengindikasikan bahwa responden memiliki sikap yang baik dalam mengatasi masalah kekerasan terhadap perempuan. Sikap seperti ini juga sangat mendukung upaya menghapus kekerasan terhadap perempuan yang merupakan salah satu dari 3 program Kementerian PPA yakni Three Ends (hapus kekerasan terhadap perempuan, hentikan pergadangan perempuan, dan hapus diskriminasi ekonomi).

Sikap responden terkait kecenderungan pencabutan kembali laporan polisi tentang kasus-kasus KDRT, data table 2 menunjukkan bahwa ketergantungan ekonomi tidak menjadi alasan untuk melaporkan Suami kepada yang berwenang apabila melakukan kekerasan dalam rumah tangga. Ada sebanyak 87 persen responden yang menyatakan tidak setuju dan sangat tidak setuju, karena alasan ketergantungan ekonomi, maka pelaku 
VIVABIO

Jurnal Pengabdian Multidisiplin kekerasan tidak dilaporkan. Data ini menunjukkan bahwa sikap masyarakat juga mulai terbuka bahwa kekerasan terhadap perempuan, siapapun pelakunya haruslah ditindak sesuai aturan hukum yang berlaku. Indikasi lainnya adalah kemandirian perempuan, sehingga ketergantungan ekonomi tidak menjadi alasan untuk tidak melaporkan pelaku.

\section{Tindakan menghadapi Perempuan dan Anak}

dalam terhadap

Terkait tindakan yang akan dilakukan masyarakat bila terjadi kekerasan terhadap perempuan dan anak, dapat dilihat dari data Tabel 3.

Tabel 3. Tindakan Masyarakat terhadap Kekerasan terhadap Perempuan

\begin{tabular}{|c|c|c|c|c|c|c|c|c|c|c|c|}
\hline \multirow[b]{2}{*}{ No } & \multirow[t]{2}{*}{ Pernyataan } & \multicolumn{2}{|c|}{ S S } & \multicolumn{2}{|l|}{$\mathrm{S}$} & \multicolumn{2}{|c|}{$\mathrm{T} \mathrm{S}$} & \multicolumn{2}{|c|}{ STS } & \multicolumn{2}{|l|}{$\mathrm{Jml}$} \\
\hline & & $\mathrm{F}$ & $\%$ & $\mathrm{~F}$ & $\%$ & $f$ & $\%$ & $\mathrm{~F}$ & $\%$ & $\mathrm{f}$ & $\%$ \\
\hline 1 & $\begin{array}{l}\text { Keluarga besar harus diberi tahu bila } \\
\text { ada kejadian kekerasan terhadap } \\
\text { anggota keluarga }\end{array}$ & 17 & 29.8 & 35 & 61.4 & 4 & 7.0 & 1 & 1.8 & 57 & 100 \\
\hline 2 & $\begin{array}{l}\text { Pemerintah Nagari harus } \\
\text { menyelenggarakan pelayanan } \\
\text { perlindungan terhadap perempuan dan } \\
\text { anak }\end{array}$ & 33 & 57.9 & 23 & 40.4 & 1 & 1.8 & 0 & 0 & 57 & 100 \\
\hline 3 & $\begin{array}{l}\text { Dukungan untuk korban kekerasan } \\
\text { terhadap perempuan dan anakk cukup } \\
\text { dari keluarga saja }\end{array}$ & 19 & 33.3 & 31 & 54.4 & 5 & 8.8 & 2 & 3.5 & 57 & 100 \\
\hline 4 & $\begin{array}{l}\text { Bantuan dari tetangga, tokoh } \\
\text { masyarakat setempat, diperlukan } \\
\text { karena KDRT bukanlah masalah } \\
\text { pribadi/keluarga }\end{array}$ & 17 & 29.8 & 27 & 47.4 & 10 & 17.5 & 3 & 8.1 & 57 & 100 \\
\hline 5 & $\begin{array}{l}\text { Bantuan dapat diperoleh dari tenaga } \\
\text { kesehatan, pengacara, LSM, pemuka } \\
\text { agama }\end{array}$ & 23 & 40.4 & 31 & 54.4 & 2 & 3.5 & 2 & 3.5 & 57 & 100 \\
\hline
\end{tabular}

Data Tabel 3 menunjukkan bahwa sebahagian besar responden setuju untuk memberi tahu keluarga besar apabila terjadi kasus kekerasan dalam rumah tangga. Sebanyak 29.8 persen responden menyatakan sangat setuju, dan 61.4 persen menyakan setuju. Artinya korban tidak akan merahasiakan kekerasan yang dialaminya kepada keluarga besar. Korban kekerasan idealnya mendapatkan perlindungan dari orang lain. Hal ini penting untuk membantu pemulihan kepercayaan diri, harga diri, menghilangkan rasa takut, dll.

Data table 3 juga menunjukkan bahwa responden tidak hanya memerlukan bantuan dari keluarga besar apabila mengalami kasus kekerasan, tetapi juga menyatakan bahwa Nagari juga harus berperan. Sebanyak 57.9 persen responden menyatakan sangat setuju dan 40.4 persen menyatakan setuju bahwa Nagari harus menyediakan layanan terhadap perempuan dan anak korban kekerasan. Pada umumnya responden setuju bahwa bantuan dapat diperleh dari berbagai lembaga layanan. Artinya, responden sudah dapat berbuat apabila terjadi kasus-kasus kekerasan terhadap perempuan dan anak. Mereka sudah paham tempat-tempat melapor dan meminta bantuan. Sebanyak 40.4 persen responden sangat setuju dan 54.4 persen setuju apabila ada masalah kekerasan terhadap perempuan anak maka lembaga layanan seperti Kepolisian, Puskesmas, P2TP2, LSM dan yang lainnya dapat dimintai bantuan. Selain itu, bantuan juga dapat diperoleh dari tokoh-tokoh masyarakat.

Berdasarkan data di atas dapat disimpulkan bahwa penyuluhan telah meningkatkan pengetahuan, sikap yang baik, tindakan yang tepat oleh masyarakat dalam upaya mencegah dan menangani masalah kekerasan terhadap perempuan dan anak di Nagari/ Desanya. 
VIVABIO

Jurnal Pengabdian Multidisiplin

\section{KESIMPULAN DAN SARAN}

Berbagai upaya untuk menghapus kekerasan terhadap perempuan dan anak harus terus dilakukan secara liat, oleh berbagai pihak dan di berbagai level masyarakat baik di kota maupun di desa. Hal ini penting karena berbeda dengan tindak kejahatan lainnya, kekerasan terhadap perempuan diselimuti relasi gender yang tidak seimbang antara laki-laki dan perempuan. Nilai-nilai patriarkhi yang cenderung menomorduakan perempuan menjadi pendorong kuat terjadinya dan berkepanjangannya kasus-kasus kekerasan terhadap perempuan dan anak. Meningkatkan pengetahuan masyarakat di akar rumput dan kepedulian pemerintah di level Desa akan relative lebih efektif untuk menghapus kekerasan terhadap perempuan dan anak sejak dini. Peluang ini semakin terbuka untuk dilakukan karena Desa memiliki legalitas untuk merencanakan program dan penganggaran yang responsive gender, salah satunya program penghapusan kekerasan terhadap perempuan dan anak.

\section{UCAPAN TERIMAKASIH}

Terimakasih diucapkan kepada Universitas Negeri Padang melalui LP2M yang telah memberi dukungan dana (PNBP tahun 2019) kegiatan pengabdian masyarakat ini. Terima kasih juga disampaikan kepada Wali Nagari Pasie Laweh dan masyarakat yang telah bersedia bekerjasama sehingga program ini dapat terlaksana sebagaimana mestinya, dan berkelanjutan.

\section{DAFTAR PUSTAKA}

Banton, O., \& West, K. 2019. "Gendered perceptions of sexual abuse: investigating the effect of offender, victim and observer gender on the perceived seriousness of child sexual abuse". Journal of child sexual abuse, 1-16.

Catahu. Komnas Perempuan 2019.

Fatimah, S. 2012. "Gender dalam Komunitas Masyarakatminangkabau ; Teori, Praktek Dan Ruang Lingkup Kajian”. Jurnal Ilmiah Kajian Gender. Volume 2 Nomor 1.

Fatmariza \& Febriani R. 2019. Domestic Violence and The Role of Women in Modern Minangkabau Society.
INCOLWIS,August 29-30. DOI 10.4108/eai.29-8-2019.2288950

Fatmariza. 2018. Pencegahan Kekerasan terhadap Perempuan dan pelecehan Seksual terhadap Anak Berbasis Kampuang. Laporan Kegiatan PKM

Fatmariza.2008. Kekerasan terhadap perempuan dan anak di Sumatera Barat. Laporan Penelitian. Balitbangda Propinsi Sumatera Barat

Tundjung HS. et al. 2019. "Peningkatan Kesadaran Hukum Masyarakat terhadap Peran Masyarakat dalam Pencegahan dan Penanggulangan Kekerasan dalam Rumah Tangga". Jurnal Bakti Masyarakat Indonesia. Volume 2 Nomor 2

Klugman, J. 2017. "Gender Based Violence and the Law", World Development Report, 2017, hal. 3

Muhajarah, K. 2016. "KEKERASAN TERHADAP PEREMPUAN DALAM RUMAH TANGGA: Perspektif SosioBudaya, Hukum, dan Agama". SAWWA. Volume 11 Nomor 2.

Purnamasari, S et al. 2019. "Upaya Pencegahan Kekerasan Terhadap Anak dan Perempuan dalam Menciptakan Lingkungan Ramah Keluarga". Jurnal Loyalitas Sosial. Volume 1 Nomor 2

Rifa'at, M. 2019. "Kekerasan terhadap Perempuan dalam Ketimpangan Relasi Kuasa: Studi Kasus di Rifka Annisa Women's Crisis Center". SAWWA : Jurnal Studi Gender. Volume 14 Nomor 2

Rohmawati . 2016. "Eliminasi Domestic Violence Berbasis Komunitas". Proceedings Of The International Conference On University-Community Engagement.

Seda, Francisia, S.S.E, et al. 2012. "Relasi Gender dalam Masyarakat Indonesia" dalam Wirutomo, Paulus, dkk. Sistem Sosial Indonesia. Jakarta: UI Press

Sutrisminah, E. 2012. "Dampak Kekerasan Pada Istri Dalam Rumah Tangga Terhadap Kesehatan Reproduksi”. Majalah Ilmiah Sultan Agung. Volume 50 Nomor 127

Undang-Undang no 23 tahun 2004 tentang Penghapusan Kekerasan Dalam Rumah Tangga

Wadjidi, F. 1993. "Perempuan dan Agama". dalam Ridjal (ed) Dinamika Gerakan 
VIVABIO

Volume 2 Nomor 1, April 2020: 8-16. ISBN 2685-1091

Jurnal Pengabdian Multidisiplin

Perempuan Di Indonesia Yogyakarta:

PT. Tiara Wacana 